\title{
The Influence of "Soft" and "Hard" Total Quality Management (TQM) Practices on Total Productive Maintenance (TPM) in Jordanian Manufacturing Companies
}

\author{
Ayman Bahjat Abdallah ${ }^{1}$ \\ ${ }^{1}$ Faculty of Economics and Administrative Sciences, Applied Science University, Jordan \\ Correspondence: Ayman Abdallah, Department of Business Administration, Faculty of Economics and \\ Administrative Sciences, Applied Science University, Amman, Jordan. Tel: 962-786-951282. E-mail: \\ aymanabdallah@yahoo.com
}

Received: July 29, 2013

Accepted: September 18, 2013

Online Published: October 15, 2013

doi:10.5539/ijbm.v8n21p1

URL: http://dx.doi.org/10.5539/ijbm.v8n21p1

\begin{abstract}
Numerous studies have been separately carried out on total quality management (TQM) and total productive maintenance (TPM). This paper examines the influence of soft and hard TQM practices on TPM implementation level at manufacturing companies in Jordan using survey data and empirical research methodology. The results indicate that four soft TQM practices, top management leadership, training, workforce management, and customer focus, significantly and positively affect TPM implementation level. The results also show that three hard TQM practices, continuous improvement, information feedback, and process management, significantly and positively affect TPM implementation level.
\end{abstract}

Keywords: total quality management, soft TQM practices, hard TQM practices, total productive maintenance

\section{Introduction}

Total quality management received substantial consideration from researchers in the past two decades. Many researchers have investigated the interrelationship among quality constructs as well as the impact of quality management on quality performance, business performance, and operational performance (e.g. Flynn et al., 1995; Dow et al., 1999; Samson \& Terziovski, 1999). Researchers also investigated the effect of quality management on different operational practices such as just-in-time production, mass customization, supply chain management, new product development, and product variety. Only few research papers have made an explicit distinction between soft and hard TQM practices implying that this area is not fully investigated.

Maintenance activities are essential for achieving and maintaining competitiveness of manufacturing companies as 40 per cent of operational cost of a manufacturer is related to maintenance activates (Hora, 1987; Ahuja \& Khamba, 2008). Quality management alone is inadequate to manage maintenance activities plant wide because to the partial influence of quality management on machine performance (McKone et al., 1999). Total productive maintenance is an extensively used maintenance strategy that was originated in Japan. TPM is some times regarded as an extension of TQM strategy for machinery for eliminating breakdowns (Tajiri \& Gotoh, 1992). Despite the fact that the two concepts (TQM and TPM) have many common attributes, the interaction effect of the two concepts has been mainly overlooked by many manufacturing companies, accompanied by disregarding maintenance management as a distinctive competence leading to competitive advantage (Wireman, 1990). Such situation unfavorably influence competitive performance dimensions at manufacturing companies such as inventory levels, product quality, and delivery performance, in addition to bringing down the dependability of plants and reducing machine availability due to equipment downtime (Ahuja \& Khamba, 2008). While reviewing the literature; few research papers concerning TQM-TPM relationship were found. None of these papers investigated the influence of TQM in terms of soft and hard aspects on TPM. Additionally, majority of these papers came from developed countries. In this paper we attempt to fill this gap by investigating the influence of soft and hard TQM practices on TPM using an empirical approach in Jordan which is considered a developing country. 


\section{Literature Review}

\subsection{Total Quality Management (TQM)}

Since the diffusion of the TQM concept in the mid-1980s, many organizations all over the world have adopted it. Spitzer (1993) argued that TQM is the only approach for companies to attain superior and sustainable operational performance.

TQM has been defined as a comprehensive company-wide approach for meeting or exceeding the requirements and expectations of customers that entails the participation of every one in the organization in using quantitative techniques to continually improve the products, services, and processes of the company (Psychogios \& Priporas, 2007). Top management leadership plays a fundamental role in introducing and facilitating the implementation of TQM strategy by creating a learning and cooperative environment that leads to customer satisfaction, continuous improvement, and employee involvement (Anderson et al., 1994).

While many published research papers used both soft and hard TQM constructs to measure TQM philosophy, an explicit distinction between soft and hard constructs was not made in many of these papers (Abdullah \& Tari, 2012). Soft and hard aspects are some times called the management system and the technical system (Evans \& Lindsay, 1999).

Abdullah and Tari (2012) indicated that there is a lack of consensuses among researchers regarding the measurement scales of soft and hard TQM practices. They reported that soft elements relate to human aspects, while hard elements are more related to the tools and techniques of quality, process management and measurement, and design procedures.

\subsubsection{Soft TQM Practices}

Soft practices are long term factors that are related to management issues and aspects and must be considered and targeted in a company's TQM strategy and subsequent implementation plan (Lewis et al., 2006a; Vouzas \& Psyhogios, 2007). Soft practices generally deal with human resource management and concentrates on behavioral sides including training for employees, management leadership, teamwork, supplier relationship and management, creating value to customers, and achieving customer satisfaction (Lewis et al., 2006a; Gadenne \& Sharma, 2009; Lewis et al., 2006b). In order to maximize the effect of soft practices, they should be enhanced by the hard TQM practices (Zairi \& Thiagarajan, 1997). Soft practices are harder to quantify and, therefore, the measurement and assessment of them is a challenging issue for management (Samson \& Terziovski, 1999). Powell (1995) asserted that organizations that have implemented soft TQM practices can perform better than competitors without the associated TQM philosophy.

\subsubsection{Hard TQM Practices}

Hard TQM practices are related to improvement tools and systems of quality management and are expected to enhance and support the implementation of soft TQM practices (Lewis et al., 2006a; Oakland, 2000; Vouzas \& Psyhogios, 2000). Hard aspects generally include practices such as quality systems, continuous improvement, process management, and information feedback (Lewis et al., 2006a; Gadenne \& Sharma, 2009). While soft aspects are regarded as intangible, hard aspects are more tangible and, therefore, easier to be measured and assessed (Gadenne \& Sharma, 2009). The importance of hard aspects of TQM should not be underestimated. Deming (1986) pointed to the crucial role of hard aspects by stating "in God we trust - all others must use data". Goetsch and Davis (1994) defined management tools as "collecting and displaying information in ways to help the human brain grasp thoughts and ideas that, when applied to physical processes, cause the processes to yield better results".

\subsubsection{Previous Studies on Soft and Hard TQM Aspects}

Literature has reported mixed results concerning the importance of soft and hard TQM practices and their impact on TQM success and performance. It should be noted that different researchers used different practices to measure soft and hard aspects of TQM, and this may explain the contradicting results reported in the literature. Fotopoulos and Psomas (2009) using an empirical data from 370 Greek companies found that soft TQM practices strongly affected quality management while hard TQM practices had only a limited effect. Abdullah et al. (2008) found that soft TQM practices which included customer focus, leadership, and employee involvement had significantly contributed to performance. Dow et al. (1999) using empirical data from Australian manufacturing companies found that only three soft practices of TQM: customer focus, employee commitment, and shared vision, significantly contributed to organizational performance, while hard practices which included benchmarking, statistical process control, and flexible manufacturing systems did not affect performance significantly. Other researchers concluded that soft TQM aspects were related to TQM success or superior 
performance (e.g., Powell, 1995; Samson \& Terziovski, 1999; Terziovski et al., 2003; Ahire et al., 1996; Demirbag et al., 2006). Lewis et al (2006b) asserted that hard practices are easier to be managed by SMEs than soft practices as they can be certainly measured. They found that hard practices of TQM such as continuous improvement and systems development were more implemented by SMEs than soft practices.

On the other hand, other researchers found that both soft and hard TQM practices contributed to TQM success or superior performance. Gadenne and Sharma (2009) used a questionnaire to investigate the key soft and hard TQM practices used by Australian SMEs. They found that performance was affected by soft as well as hard TQM practices. Soft practices contributing to performance included management leadership, training, supplier relationship, and increased internal and external interaction. Hard practices contributing to performance included continuous improvement, benchmarking, improvement of efficiency, and measurement of quality. Lagrosen and Lagrosen (2005) found a positive association between successful quality management initiative and both soft and hard TQM practices. They pointed to three soft TQM practices as most crucial which were fact-based management, continuous improvement, and participation of all employees. Bayazit (2003) found based on a data of a survey in Turkey that both soft and hard TQM elements influenced TQM success. He further concluded that hard TQM practices alone could not improve customer satisfaction and continuous process improvement, without proper support by soft TQM aspects such as management leadership, employee involvement, and supplier support. Flynn et al. (1995) found that both soft and hard TQM practices were associated with performance. Soft practices related to performance included workforce management, top management support, work attitudes, and supplier relationship, while hard practices related to performance included product design, process and statistical process control.

\subsection{Total Productive Maintenance (TPM)}

As defined by Nakajima (1988), TPM "is a plant improvement methodology, which enables continuous and rapid improvement of manufacturing processes through the use of employee involvement, employee empowerment and closed loop measurement of results". Another definition of TPM was proposed by Imai (1986): "TPM aims at maximizing equipment effectiveness with a total system of preventive maintenance covering the entire life of the equipment involving everyone in all departments and at all levels, it motivates people for plant maintenance through small-group and voluntary activities".

TPM has several benefits as reported in the literature. Such benefits include improvements in productivity, delivery, safety, employee satisfaction, reduced costs of maintaining equipments and processes, reduced idle time and minor stoppages, less time in adjustments and setups, reduced defects, spillages, process upset conditions, improved financial performance and profitability, and increased sales and market share (Nakajima, 1988; Steinbatcher \& Steinbatcher, 1993). Cross (1988) stated that maintenance cost represented a significant portion of the total plant cost which might reach up to 23 per cent.

To measure the performance of TPM, overall equipment effectiveness (OEE) is usually used (Nakajima, 1988). OEE measures six types of waste that TPM attempts to minimize: machine failure, setup and changeover, defect and rework, start up losses, idling stoppage, and speed losses (Nakajima, 1988; Tajiri \& Gotoh, 1992).

There are major activities, or pillars that support TPM which include: elimination of six big losses, planned maintenance, autonomous maintenance, improved skills of employees, and an initial machine management program (Nakajima, 1988; Tajiri \& Gotoh, 1992; Suzuki, 1994). The main principles of TPM consist of teams of small groups, employee participation and involvement, autonomous maintenance activities by operators, and maintainability and productivity (Ahuja \& Khamba, 2008). Usually an autonomous maintenance program needs 3-4 years to be established and the activities of autonomous maintenance are carried out by production department, mainly operators, with assistance of maintenance department (Tajiri \& Gotoh, 1992). According to Swanson (2001), the four main elements of TPM are training of people, involvement of people, preventive maintenance, and teams. Preventive maintenance is an important aspect of TPM. It includes daily maintenance, periodic maintenance as well as condition monitoring including medium and long interval servicing (Nakazato, 1994).

TPM strategy requires training of employees and teams at all levels and from different departments, and a reliable information feedback (Ahuja \& Khamba, 2008). Teamwork is: "the management system that organizes people into natural unit teams and/or high performance teams in order to accomplish a company's stated goals and objectives" (Maggard, 1992). Support to maintenance activities represents one important dimension of TPM (Nakajima, 1988; Tajiri \& Gotoh, 1992; Suzuki, 1994). This includes the involvement and commitment of top management and their direct participation of TPM activities. In addition, planned maintenance should be included in the production scheduling at regular intervals. Planned maintenance activities according to Suzuki 
(1994) "emphasize monitoring mean time between failure and using that analysis to specify the intervals for tasks in annual, monthly, and weekly maintenance calendars".

Teams and small group activities are at the center of TPM with everyone involved in TPM activities. Activities associated with TPM teams and small groups have to be regarded as part of the formal organization and should be fit to the existing organizational units, and these activities are part of everyone's job (Ichikawa, 1994). A Team should include workers who operate the machines, workers from the maintenance department, representatives of supervisors and higher management, and schedulers (Sun et al., 2003). TPM small group activities are based on zero-defect concept and built into the organizational framework (Nakajima, 1988).

Japan Institute of Plant Maintenance (JIPM) initiated a global TPM award in order to promote TPM implementation. Companies from all over the world are invited to participate. The assessment of applicants is based on the achievements done to improve machine maintenance and performance, minimize sudden accidents, improve productivity, and improve work conditions (Brah \& Chong, 2004).

\subsection{Previous Studies on TQM-TPM Relationship}

As for the literature concerning TQM-TPM relationship, mixed results have been reported. Some researchers argued that TQM should be implemented prior to introducing TPM program. For instance, Dale (1999) stated that TQM supports the implementation level of TPM since the origins of the latter are built upon TQM strategy. Similarly, Yamashima (2000) asserted that TPM has risen from the ideas of TQM as an autonomous improvement strategy. Konecny and Thun (2011) argued that TQM practices support and facilitate TPM. They indicated that each of the two improvement strategies (TQM and TPM) consists of basic aspects that are distinctive to each strategy. Seth and Tripathi (2006) found that the combined application of TQM and TPM at Indian manufacturing companies significantly improved operational performance. Other authors reported that the implementation of the two programs was highly correlated (e.g. Cua et al., 2006; Flynn et al., 1995; Sriparavastu \& Gupta, 1997). A small number of researchers stated that TPM supports TQM and therefore should be implemented prior to TQM introduction. For instance, Ahmad et al. (2012) indicated that TPM should be implemented prior to introducing statistical process control. Their justification is that TPM leads to consistent and stable output of processes due to limited variability of machines, which is necessary as SPC entails such stable processes in order to accurately eliminate irregular causes. McKone et al. (2001) concluded that TPM indirectly enhances manufacturing performance by facilitating TQM strategy. They measured TPM in terms of autonomous maintenance (house-keeping; cross-training; and teams) and planned maintenance (operator involvement; disciplined planning; and information tracking).

\section{Framework and Research Hypotheses}

\subsection{Research Framework}

The research framework is shown in Figure 1. The framework reflects the influence of soft and hard TQM practices on TPM implementation level. The research measures and hypothesized relationships are discussed in this section.

Soft TQM Practices
- Customer focus
- Training
- Top management leadership
- Workforce management
- Supplier relationship
Hard TQM Practices
- Continuous improvement
- Information feedback
- Statistical process control
- Process management
- Tools and techniques

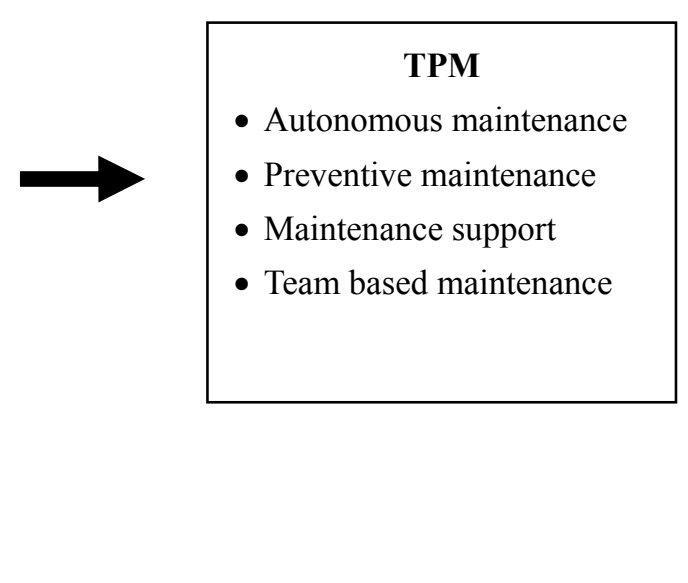

Figure1. Research framework 


\subsection{Research Measures}

\subsubsection{Soft TQM Measures}

On the basis of the literature review, the following dimensions to measure soft TQM practices were introduced:

1) Customer focus: the belief of all organizational members that customers are the best source to identify their wants and needs, customer satisfaction is essential to achieve superior performance, and that the organization should satisfy or exceed requirements and expectations of the customers.

2) Training: provision of training and education on quality techniques and tools to most of employees and the allocation of necessary resources for such training activities.

3) Top management leadership: the involvement of top management in developing a strategy based on quality improvement, the personal participation of plant managers in quality improvement projects, and the encouragement of employee involvement in improving the quality of products and processes.

4) Workforce management: encouraging team work and group discussions, exchange opinions and ideas, payment of a team incentive for ideas leading to quality improvements, perform multiple tasks by the plant works, and reward workers for acquiring new working practices and skills.

5) Supplier relationship: establishment of lasting relationships with suppliers, the participation of suppliers in new product development activities, engagement of suppliers in improvement activities associated with quality, and selecting suppliers based on quality.

\subsubsection{Hard TQM Measures}

Based on the extensive review of the published literature, the following five hard TQM practices were introduced:

1) Continuous improvement: is a continuing attempt to improve all aspects of business so that performance is made as a moving goal which is difficult for rivals to imitate or outperform, and the belief that improvement is an endless journey.

2) Information feedback: making extensive use of information related to quality activities and performance and making it available to all employees, such information usually includes rate of equipment breakdowns, schedule compliance, and fault rate.

3) Statistical process control (SPC): monitoring the production processes and reducing the variance related to their performance using statistical methods, and using charts to verify whether the production processes are in control.

4) Process management: the belief that the process is the entity that should be managed in order to eliminate or minimize errors, and the belief that improvements related to production processes will necessarily improve the overall quality performance.

5) Tools and techniques: the use of quality diagrams and analysis such as relations diagram, affinity diagram, cause and effect diagram, scatter diagram, force-field analysis, and quality function deployment.

\subsubsection{TPM Measures}

On the basis of the literature review, the following dimensions to measure TPM were introduced:

1) Autonomous maintenance: the participation of employees in inspecting and cleaning their machines, and their capability to identify and correct irregular conditions of their machines.

2) Preventive maintenance: using diagnostic methods to forecast machine lifespan, making use of technical analysis to highlight main breakdowns of machines, and improving poor-performed machines including redesign if necessary.

3) Maintenance support: the existence of planned maintenance activities, plant-wide maintenance standards, and accurate maintenance information systems.

4) Team-based maintenance: the promotion of teams from different departments as well as the creation of small groups for solving problems related to machine performance.

\subsection{Research Hypotheses}

\subsubsection{Soft TQM Practices and TPM}

Many companies have initiated TPM programs, however, less than 10 per cent succeeded in implementing such a program (Mora, 2002). TPM implementation process entails the alteration of organizational culture and 
modification of behaviors of everyone in the organization. Furthermore, TPM represents a company-wide methodology to machine management that involves all the employees in the company, from upper management to operators, and production personnel to suppliers, resulting in minimizing machine downtime, accidents, and defect rates (Ahjuja \& Khamba, 2008). They also stated that the objectives of TPM require strong management support, small group activities, and continuous use of work teams to achieve incremental improvements. For successful implementation of TPM program, barriers between maintenance and production departments should be broken down; moreover, TPM requires an enhanced problem solving skills and cross-functional learning and cooperation (McKone et al., 2001). Cooke (2000) pointed to the significance of management leadership and support, training and education, change management, communication, and independence to employees for TPM success. Tsang and Chan (2000) also found that top management leadership, education and training, employee participation and involvement, and communication are necessary for TPM successful implementation. Soft aspects of TQM philosophy are expected to provide such necessary infrastructure and facilitate TPM implementation in manufacturing companies. TPM shares many infrastructural aspects with TQM such as human-resource oriented practices, committed leadership, cross-functional employees, multiple task and skill development, employee involvement, and continuous improvement (Cooke, 2000; Linderman et al., 2005; Konecny \& Thun, 2011). Brah and Chong (2004) pointed to the importance of incorporating customer focus with TPM program which will result in productivity improvement, waste reduction, gathering and analyzing of data, timeliness and planning of activities. TQM alone is insufficient to manage maintenance program as productive maintenance concentrates on machine effectiveness, whereas TQM program do not pay attention to detailed planned maintenance programs (Al-Hassan et al., 2000). However, based on the previous arguments, it could be asserted that soft aspects of TQM are crucial to ensure successful TPM implementation.

H1: Customer focus will be positively related to TPM.

H2: Training will be positively related to TPM.

H3: Top management leadership will be positively related to TPM.

H4: Workforce management will be positively related to TPM.

H5: Supplier relationship will be positively related to TPM.

\subsubsection{Hard TQM Practices and TQM}

TPM successful implementation requires several tools to solve and analyze problems related to equipment such as Pareto analysis, statistical process control, continuous improvement, recognition and reward program, waste minimization, and cause-effect diagrams (Jostes \& Helms, 1994). Additionally, TPM requires a unique information system that is capable to track the information concerning equipment performance and to capture all the necessary information about equipment failure (Suzuki 1994). Brah \& Chong (2004) pointed to the crucial role of continuous improvement, process management and focus, and information gathering and analysis for successful TPM implementation. The information system is necessary to review and refine the implementation of TPM program (Suzuki, 1994; Brah \& Chong, 2004). Moreover, statistical process control and the information provided are expected to support TPM implementation levels (McKone et al., 1999; Brah et al., 2002). The significance of process focus and management lies on its role to support autonomous maintenance and continual improvements and keeping up safety standards (Brah \& Chong, 2004). McKone et al. (1999) concluded that companies with higher process focus, good information tracking systems, efficient teams, and high operator involvement were in a favorable position to implement TPM successfully. Muthu et al. (2001) argued that the strategy of TPM aims at applying TQM in maintenance side. They asserted that quality system should be incorporated to enhance the maintenance system.

Based on the pervious arguments, hard aspects of TQM are expected to support and facilitate TPM implementation.

H6: Continuous improvement will be positively related to TPM.

H7: Information feedback will be positively related to TPM.

H8: Statistical process control will be positively related to TPM.

H9: Process management will be positively related to TPM.

H10: Tools and techniques will be positively related to TPM. 


\section{Methodology}

\subsection{Data Collection}

The author of this paper used a questionnaire that was appropriately structured to cover all the aspects of TQM and TPM discussed in the previous sections. The questionnaire was administered on a broad range of manufacturing companies in Jordan. The questionnaire was designed to elicit information from production or plant managers, quality managers, maintenance managers, and top level managers. In Jordan it is difficult to get proper and adequate response if questionnaires were sent by mail or e-mail. The author visited each company personally to meet and request the managers to fill out the questionnaire in his presence in order to increase the reliability of answers; however, in most instances managers were declining claiming that they were busy, and asking to come back in few days to collect the answered questionnaires. About 28 questionnaires were filled out in the presence of the author. The population of this research was defined as all Jordanian manufacturing companies in the private sector. Government controlled or public corporations were not included in this study. Companies in sectors other than manufacturing were also excluded from this study. To achieve a fair level of representation, two hundred manufacturing companies were visited, covering electronic/electrical, machinery, textile, food, industrial, medical, chemical and others. The companies covered under this survey differed in size and type of products manufactured. To ensure content validity, the author conducted an extensive literature review to develop the measurement instrument of this research. The questionnaire was pre-tested at two manufacturing plants by two production engineers to verify that the conceptual and practical perspectives identified by the researcher were suitable to manufacturing companies in Jordan, and the terminology used is understood by all of them. The questionnaire was also pilot-tested by three academics and revised as needed. The questionnaire was written in English as engineers in Jordan prefer to use English language for technical purposes and scientific communication since the medium of instructions in the Engineering faculties in Jordanian universities is English language. The questionnaire used in this research will be available from the author upon request. Usable responses of 119 companies were received resulting in response rate of 59.5 per cent as shown in Table 1.

Table 1. Survey responses rate

\begin{tabular}{lc}
\hline Number of visited companies & 200 \\
Total responses & 127 \\
Unusable responses & 8 \\
Final usable responses & 119 \\
Useable responses rate (\%) & 59.5 \\
\hline
\end{tabular}

\subsection{Measurement Analysis}

Five multi-item constructs were used to measure soft TQM practices and five multi-item constructs to measure hard TQM practices. To measure TPM, four multi-item constructs were used. Responding engineers and managers were asked to evaluate their agreement or disagreement with the survey question items using seven-point Likert scales, where 1 indicated strongly disagree and 7 indicated strongly agree. The average of TPM scales was computed as an overall scale and was used in the subsequent analysis. To ensure construct validity, within-scale factor analysis was carried out with principal component's analysis (PCA) as the extraction method to verify that all items loaded onto one factor with eigenvalue of at least 1 . Only question items that showed a factor loading more than 0.40 with the factor were retained.

To assess the reliability of the research constructs, Cronbach's $\alpha$-coefficient was selected. All constructs including TPM overall scale met the recommended standard of $\alpha \geq 0.60$ (Nunnally, 1978). Table 2 below shows the mean values, standard deviations, and cronbach's $\alpha$-coefficients for the measurement scales used in this study. 
Table 2. Means, standard deviations, and cronbach's $\alpha$-coefficient

\begin{tabular}{lccc}
\hline Variable & Mean & Standard deviation & Cronbach's $\alpha$-coefficient \\
\hline Autonomous Maintenance & 5.175 & 0.5471 & 0.683 \\
Preventive Maintenance & 4.868 & 0.6934 & 0.681 \\
Maintenance Support & 4.711 & 0.7942 & 0.672 \\
Team-Based Maintenance & 4.890 & 0.6589 & 0.655 \\
TPM overall scale & 4.911 & 0.5562 & 0.836 \\
Customer Focus & 5.046 & 0.5076 & 0.682 \\
Training & 5.669 & 0.4758 & 0.824 \\
Leadership & 5.527 & 0.3932 & 0.772 \\
Workforce Management & 5.384 & 0.6493 & 0.744 \\
Supplier Relationship & 4.821 & 0.8244 & 0.775 \\
Continuous Improvement & 4.987 & 0.4819 & 0.716 \\
Information Feedback & 5.570 & 0.5878 & 0.799 \\
SPC & 3.788 & 0.7730 & 0.796 \\
Process Management & 5.421 & 0.5012 & 0.816 \\
Tools and Techniques & 4.103 & 0.8104 & 0.706 \\
\hline
\end{tabular}

\section{Results and Discussion}

Hierarchical regression analysis was used to test the research hypotheses. In order to ensure that the results of the regression models could be generalized, the assumptions underling regression analyses were tested. The residual analysis revealed that the assumptions concerning linearity, homoscedasticity, normality, and independent error terms were not violated. Two regression models were used to test the influence of soft and hard TQM practices on TPM implementation level. The first multiple regression model was used to test hypotheses $\mathrm{H} 1, \mathrm{H} 2, \mathrm{H} 3, \mathrm{H} 4$, and $\mathrm{H} 5$ concerning the influence of soft TQM practices on TPM as shown in table 3. Overall TPM measure was used as a dependent variable and the five soft TQM practices were entered as independent variables. It was expected that the soft TQM practices were highly correlated, and this situation may lead to multicollinearity which causes unreliable results. Variance inflation factor (VIF) was used to deal with this problem. VIF in the regression model ranged between 1.520 and 2.176. These values were below the 2.5 level pointed by Allison (1999) as an indicator of muliticollinearity; therefore, multicollinearity was not a concern in this model. The results of the regression model showed that four soft TQM practices, customer focus, training, top management leadership, and workforce management were positively and significantly associated with TPM. Supplier relationship was insignificantly associated with TPM. Hypotheses H1, H2, H3, and H4 were accepted while hypothesis $\mathrm{H} 5$ was rejected.

The second multiple regression model was used to test hypotheses H6, H7, H8, H9, and H10 concerning the influence of hard TQM practices on TPM. In a similar manner, overall TPM measure was used as a dependent variable, while the five hard TQM practices were entered as independent variables as shown in Table 4. VIF in this regression model ranged between 1.132 and 2.040 indicating that multicollinearity was not a concern in this model as well. The results of the second regression model showed that three hard TQM practices, continuous improvement, information feedback, and process management were positively and significantly associated with TPM. Statistical process control and tools and techniques were insignificantly associated with TPM. Hypotheses $\mathrm{H} 6, \mathrm{H} 7$, and $\mathrm{H} 9$ were accepted while hypotheses $\mathrm{H} 8$ and $\mathrm{H} 10$ were rejected.

The results clearly indicated that both soft and hard aspects of TQM positively and significantly contributed to TPM implementation level. This is in accordance with previous literature that pointed to the importance of both soft and hard aspects of TQM (e.g. Gadenne \& Sharma, 2009; Lagrosen \& Lagrosen, 2005; Bayazit, 2003; Flynn et al., 1995). It would be unrealistic to expect high levels of TPM. 
Table 3. Hierarchical regression analysis of soft TQM on TPM

\begin{tabular}{lccc}
\hline Variables & Model Coefficients & Sig. & Collinearity Statistics (VIF) \\
\hline Constant & 0.489 & 0.166 & \\
Customer Focus & 0.154 & 0.049 & 1.678 \\
Training & 0.286 & 0.001 & 2.051 \\
Leadership & 0.418 & 0.000 & 2.176 \\
Workforce Management & 0.211 & 0.004 & 1.638 \\
Supplier Relationship & -0.080 & 0.254 & 1.520 \\
$\mathrm{R}^{2}$ & 0.623 & & \\
Adj. $\mathrm{R}^{2}$ & 0.607 & & \\
$\mathrm{~F}$ & 39.306 & 0.000 & \\
\hline
\end{tabular}

Without having been started a TQM program. Different problems are expected to appear during the TPM implementation process that may potentially impede its successful implementation. TQM provides the necessary infrastructure to support and facilitate TPM implementation.

As for individual soft TQM practices, top management leadership proved to be the most important practice that affected TPM implementation level (Beta 0.418, $\mathrm{p}<0.000$ ). This is in accordance with previous literature that pointed to the crucial role of management leadership for the success of improvement programs such as TQM and TPM (e.g. Talib et al., 2013; Powell, 1995; Flynn et al., 1994). The following most important practices that affected TPM implementation level were training (Beta 0. 286, p < 0.001) and workforce management (Beta 0. $211, \mathrm{p}<0$. 004) respectively. These results appeared natural as appropriately trained employees who are managed and encouraged to work in teams, exchange thoughts and ideas, carry out multiple tasks, and are rewarded for acquiring new skills are expected to highly contribute to TPM successful implementation in the plant. Customer focus was the least contributing soft practice to TPM (Beta 0.145, p < 0.049). Supplier relationship was insignificantly related to TPM (Beta -0.080 , $\mathrm{p}$-value $=0.254$ ). While it is widely accepted that supplier relationship practices such as lasting relations with suppliers, participation of suppliers in new product development, choosing suppliers based on quality considerations, and maintaining close communication with suppliers are expected to yield different benefits for the organization, the results showed that they had no effect on TPM implementation level.

Table 4. Hierarchical regression analysis of hard TQM on TPM

\begin{tabular}{lccc}
\hline Variables & Model Coefficients & Sig. & Collinearity Statistics (VIF) \\
\hline Constant & 0.287 & 0.464 & \\
Continuous Improvement & 0.510 & 0.000 & 2.040 \\
Information Feedback & 0.286 & 0.000 & 1.797 \\
SPC & -0.006 & 0.921 & 1.132 \\
Process Management & 0.199 & 0.001 & 1.262 \\
Tools and Techniques & 0.004 & 0.951 & 1.517 \\
$\mathrm{R}^{2}$ & 0.670 & & \\
Adj. $\mathrm{R}^{2}$ & 0.657 & & \\
$\mathrm{~F}$ & 49.181 & 0.000 & \\
\hline
\end{tabular}

As for individual hard TQM practices, continuous improvement was the most important practice that affected TPM implementation level (Beta 0.510, $\mathrm{p}<0.000$ ). The existence of continuous improvement culture company-wide that strives to improve all aspects of products and processes based on Deming cycle plan-do-check-act is expected to overcome many difficulties during TPM implementation process.

The following most important hard practice that affected TPM was information feedback (Beta 0.286, $p<0.000$ ). The availability of analytic and systematic information concerning machine breakdowns, defect rates, schedule compliance, and quality performance result in deep understanding of unexpected deviations from planned procedures and enable companies to continually maintain the condition of machines. The third hard TQM practice that affected TPM was process management (Beta 0.199, $\mathrm{p}<0.001$ ). Overall process management enables companies to achieve unique capabilities of equipment by avoiding the stoppage of production processes due to equipment breakdowns and, therefore, provides companies with an equipment advantage. Two 
practices, SPC and tools and techniques did not contribute significantly to TPM implementation level. It was interesting to note that the two practices had the lowest means among all soft and hard TQM practices as shown in Table 2. It could not be suggested that companies should not focus on SPC and quality tools and techniques because they did not contribute significantly to TPM implementation in the regression model. Nor it could be suggested that companies attempting to implement TPM should ignore these two practices. Many previous studies proved the importance of these two practices for successful TQM program. It could be suggested, however, that these two practices were less important for TPM implementation than the powerful three hard TQM practices.

\section{Conclusions}

This study investigated the influence of soft and hard TQM practices on TPM implementation level at manufacturing companies in Jordan. On the basis of the study, the following conclusions were drawn.

The results indicated that both soft and hard TQM aspects positively and significantly affected and facilitated the implementation level of TPM. Manufacturing companies are strongly recommended to initiate TQM program prior to TPM introduction. The existence of TQM program is expected to provide companies with necessary infrastructure for successful TPM implementation. Consideration should not only be given to soft aspects of TQM; rather both soft and hard aspects of TQM should be given equal consideration in order to enhance TPM implementation.

This study suggested that four soft TQM practices, top management leadership, training, workforce management, and customer focus were positively and significantly related to TPM implementation level. These practices represent the human-related infrastructure required for successful TPM implementation.

The results showed that three hard TQM practices, continuous improvement, information feedback, and process management were positively and significantly related to TPM implementation level. The findings shed more light on the importance of hard TQM practices in today's competitive environment to assist manufacturing companies to reach superior levels of TPM implementation.

The limitation of this study could be the sample size. Although the sample size was suitable for regression models, it was not sufficient to conduct path analysis in order to highlight the direct and indirect effects among variables. A second limitation was the use of single informants to collect the required information. Although most published studies use single informants, the use of multiple informants would improve the validity of the results (Jiménez-Jiménez \& Martínez-Costa, 2009).

Similar research studies should be undertaken to investigate the influence of other improvement programs such as just-in-time production and six sigma on TPM implementation level. Case studies are also needed to highlight potential problems and success factors associated with TPM implementation in developing countries.

\section{Acknowledgements}

The author is grateful to Applied Science Private University, Amman, Jordan, for the full financial support granted to this research project (Grant No. DRGS-2012-2013-30).

\section{References}

Abdullah, M., \& Tari, J. (2012). The Influence of Soft and Hard Quality Management Practices on Performance. Asia Pacific Management Review, 17(2), 177-193. http://dx.doi.org/10.1108/17542730810898412

Abdullah, M. M. B., Uli, J., \& Tari, J. J. (2008). The influence of soft factors on quality improvement and performance: perceptions from managers. The TQM Journal, 20(5), 436-52. http://dx.doi.org/10.1108/17542730810898412

Ahire, L. S., Golhar, D. Y., \& Waller, M. A. (1996). Development and validation of TQM implementation constructs. Decision Sciences, 27(1), 23-56. http://dx.doi.org/10.1111/j.1540-5915.1996.tb00842.x

Ahmad, M. F., Zakuan, N., Jusoh, A., \& Takala, J. (2012). Relationship of TQM and Business Performance with Mediators of SPC, Lean Production and TPM. Procedia-Social and Behavioral Sciences, 65(3), 186-191. http://dx.doi.org/10.1016/j.sbspro.2012.11.109

Ahuja, I. P. S., \& Khamba, J. S. (2008). Total productive maintenance: literature review and direction. International Journal of Quality \& Reliability Management, 25(7), 709-756. http://dx.doi.org/10.1108/02656710810890890

Al-Hassan, K., Fat-Lam, C., \& Metcalfe, V. (2000). The role of total productive maintenance in business excellence. Total Quality Management, $11(4 / 5 \& 6), \quad 596-601$. 
http://dx.doi.org/10.1080/09544120050007931

Allison, P. D. (1999). Multiple Regression: A Primer (1st ed.). CA: Thousand Oaks, Pine Forge Press.

Anderson, J. C., Rungtusathan, M., \& Schroeder, R. (1994). A theory of quality management underlying the Deming management method. Academy of Management Review, 19(3), 472-509. http://dx.doi.org/10.5465/AMR.1994.9412271808

Bayazit, O. (2003). Total quality management (TQM) practices in Turkish manufacturing organizations. The TQM Magazine, 15(5), 345-350. http://dx.doi.org/10.1108/09544780310502435

Brah, S. A., \& Chong, W. K. (2004). Relationship between total productive maintenance and performance. International Journal of Production Research, 42(12), 2383-2401. http://dx.doi.org/10.1080/00207540410001661418

Cooke, F. L. (2000). Implementing TPM in plant maintenance: some organizational barriers. International Journal of Quality \& Reliability Management, 17(9), 1003-16. http://dx.doi.org/10.1108/02656710010378789

Cross, J. (1988). Raising the value of maintenance in the corporate environment. Management Research News, 11(3), 8-11. http://dx.doi.org/10.1108/eb027976

Cua, K. O., McKone-Sweet, K. E., \& Schroeder, R. G. (2006). Improving performance through an integrated manufacturing program. Quality Management Journal, 13(3), 45-60.

Dale, B. G. (1999). Managing Quality (3rd ed.). Boston, MA: Blackwell.

Deming, E. (1986). Out of the crisis. Cambridge, UK: Cambridge University Press.

Demirbag, M., Koh, S. C. L., Tatoglu, E., \& Zaim, S. (2006). TQM and market orientations impact on SMEs' performance. Industrial Management \& Data Systems, 106(8), 1206-28. http://dx.doi.org/10.1108/02635570610710836

Dow, D., Samson, D., \& Ford, S. (1999). Exploding the myth: do all quality management practices contribute to superior quality performance? Production and Operations Management, 8(1), 1-27. http://dx.doi.org/10.1111/j.19375956.1999.tb00058.x

Evans, J. R., \& Lindsay, W. M. (1999). The Management and Control of Quality (4th ed.). Cincinnati: South-Western College Publishing.

Flynn, B. B., Schroeder, R. G., \& Sakakibara, S. (1995). The impact of quality management practices on performance and competitive advantage. Decision Sciences, 26(5), 659-691. http://dx.doi.org/10.1111/j.1540-5915.1995.tb01445.x

Flynn, B. B., Schroeder, R. G., \& Sakakibara, S. (1994). A framework for quality management research and associated instrument. Journal of Operations Management, 11(4), 339-366. http://dx.doi.org/10.1016/S0272-6963(97)90004-8

Fotopoulos, C. B., \& Psomas, E. L. (2009). The impact of "soft" and "hard" TQM elements on quality management results. International Journal of Quality \& Reliability Management, 26(2), 150-163. http://dx.doi.org/ 10.1108/02656710910928798

Gadenne, D., \& Sharma, B. (2009). An investigation of the hard and soft quality management factors of Australian SMEs and their association with firm performance. International Journal of Quality \& Reliability Management, 26(9), 865-880. http://dx.doi.org/10.1108/026567109110995064

Goetsch, D., \& Davis, S. (1994). Introduction to total quality: Quality, productivity, competitiveness (2nd ed.). London: Macmillan.

Hora, M. (1987). The unglamorous game of managing maintenance. Business Horizons, 30(3), 67-75. http://dx.doi.org/10.1016/0007-6813(87)90039-5

Ichikawa, A. (1994). TPM Small Group-Activities. In Suzuki, T. (Ed.), TPM in Process Industries. Portland, Oregon: Productivity Press.

Imai, M. (1986). Kaizen: The Key to Japan's Competitive Success (1st ed.). McGraw-Hill/Irwin.

Jiménez-Jiménez, J., \& Martínez-Costa, J. (2009). The performance effect of HRM and TQM: a study in Spanish organizations. International Journal of Operations \& Production Management, 29(12), 1266-1289. http://dx.doi.org/10.1108/01443570911005992 
Jostes, R. S., \& Helms, M. M. (1994). Total productive maintenance and its link to total quality management. Work Study, 43(7), 18-20. http://dx.doi.org/10.1108/EUM0000000004012

Konecny, P. A., \& Thun, J. (2011). Do it separately or simultaneously-An empirical analysis of a conjoint implementation of TQM and TPM on plant performance. Int. J. Production Economics, 133, 496-507. http://dx.doi.org/10.1016/j.ijpe.2010.12.009

Lagrosen, Y., \& Lagrosen, S. (2005). The effects of quality management - a survey of Swedish quality professionals. International Journal of Operations \& Production Management, 25(10), 940-952. http://dx.doi.org/10.1108/01443570510619464

Lewis, W. G., Pun, K. F., \& Lalla, T. R. M. (2006a). Exploring soft versus hard factors for TQM implementation in small and medium-sized enterprises. International Journal of Productivity and Performance Management, 55(7), 539-554. http://dx.doi.org/10.1108/17410400610702142

Lewis, W. G., Pun, K. F., \& Lalla, T. R. M. (2006b). Empirical investigation of the hard and soft criteria of TQM in ISO 9001 certified small and medium-sized enterprises. The International Journal of Quality \& Reliability Management, 23(8), 964-985. http://dx.doi.org/10.1108/02656710610688167

Linderman, K., McKone-Sweet, K. E., \& Anderson, J. C. (2005). An integrated system approach to process control and maintenance. European Journal of Operational Research, 164(2), 324-340. http://dx.doi.org/10.1016/J.ejor.2003.11.026

Maggard, B. N. (1992). TPM Maintenance Operations that Work (1st ed.). Cambridge, MA: Productivity Press.

McKone, K., Schroeder, R., \& Cua, K. (2001). The impact of total productive maintenance on manufacturing performance. Journal of Operations Management, $19(1), \quad 39-58$. http://dx.doi.org/10.1016/j.ejor.2003.11.026

McKone, K. E., Schroeder, R. G., \& Cua, K. O. (1999). Total productive maintenance: a contextual view. Journal of Operations Management, 17(2), 123-144. http://dx.doi.org/10.1016/S0272-6963(98)00039-4

Mora, E. (2002). The Right Ingredients for a Successful TPM or Lean Implementation. Retrieved from http://www.tpmonline.com

Muthu, S., Devadasan, S. R., Mendonca, P. S., \& Sundararaj, G. (2001). Pre-auditing through a knowledge base system for successful implementation of a QS 9000 based maintenance quality system. Journal of Quality in Maintenance Engineering, 7(2), 90-104. http://dx.doi.org/10.1108/13552510110397386

Nakajima, S. (1988). Introduction to TPM: Total Productive Maintenance (11th ed.). Cambridge: Productivity Press.

Nakazato, K. (1994). Autonomous Maintenance. In Suzuki, T. (Ed.), TPM in Process Industries. Portland, Oregon: Productivity Press.

Nunnally, J. (1978). Psychometric Theory (2nd ed.). New York, NY: McGraw-Hill.

Oakland, J. (2000). Total Quality Management: Text with Cases (2nd ed.). London: Butterworth-Heinemann.

Powell, T. C. (1995). Total quality management as competitive advantage: a review and empirical study. Strategic Management Journal, 16(1), 15-37. http://dx.doi.org/10.1002/smj.4250160105

Psychogios, A., \& Priporas, C. (2007). Understanding Total Quality Management in Context: Qualitative Research on Managers' Awareness of TQM Aspects in the Greek Service Industry. The Qualitative Report, 12(1), 40-66. http://www.nova.edu/ssss/QR/QR12-1/psychogios.pdf

Samson, D., \& Terziovski, M. (1999). The relationship between total quality management practices and operational performance. Journal of Operations Management, 17(4), 393-409. http://dx.doi.org/10.1016/S0272-6963(98)00046-1

Seth, D., \& Tripathi, D. (2006). A Critical Study of TQM and TPM Approaches on Business Performance of Indian Manufacturing Industry. Total Quality Management, 17(7), 811-824. http://dx.doi.org/10.1080/14783360600595203

Spitzer, R. D. (1993). Valuing TQM through rigorous financial analysis. Quality Progress, American Society for Quality (ASQ), 49-54.

Sriparavastu, L., \& Gupta, T. (1997). An empirical study of just-in-time and total quality management principles implementation in manufacturing firms in the USA. International Journal of Operations and Production Management, 17(2), 1215-1232. http://dx.doi.org/10.1108/01443579710182954 
Steinbatcher, H. R., \& Steinbatcher, N. L. (1993). TPM for America, What It Is and Why You Need It (1st ed.). Portland, OR: Productivity Press.

Sun, H., Yam, R., \& Wai-Keung, N. (2003). The implementation and evaluation of Total Productive Maintenance (TPM) - An action case study in a Hong Kong manufacturing company. International Journal of Advanced Manufacturing Technology, 22(3-4), 224-228. http://dx.doi.org/10.1007/s001170-002-1463-3

Suzuki, T. (1994). Overview of TPM in process industries. In Suzuki, T. (Ed), TPM in Process Industries. Portland, OR: Productivity Press.

Swanson, L. (1997). An empirical study of the relationship between production technology and maintenance management. International Journal of Production Economics, 53(2), 191-207. http://dx.doi.org/10.1016/S0925-5273(97)00113-8

Tajiri, M., \& Gotoh, F. (1992). TPM Implementation: A Japanese Approach (1st ed.). New York, NY: McGraw-Hill.

Talib, F., Rahman, Z., \& Qureshi, M. N. (2013). An empirical investigation of relationship between total quality management practices and quality performance in Indian service companies. International Journal of Quality \& Reliability Management, 30(3), 280-318. http://dx.doi.org/10.1108/02656711311299845

Terziovski, M., Power, D., \& Sohal, A. S. (2003). The longitudinal effects of the ISO 9000 certification process on business performance. European Journal of Operational Research, 146(3), 580-595. http://dx.doi.org/10.1016/S0377-2217(02)00252-7

Tsang, A. H. C., \& Chan, P. K. (2000). TPM implementation in China: a case study. International Journal of Quality \& Reliability Management, 17(2), 144-57. http://dx.doi.org/10.1108/02656710010304555

Vouzas, F., \& Psyhogios, A. G. (2007). Assessing managers' awareness of TQM. The TQM Magazine, 19(1), 62-75. http://dx.doi.org/10.1108/09544780710720844

Wireman, T. (1992). Total Productive Maintenance - An American Approach (1st ed.). New York, NY: Industrial Press Inc.

Yamashima, H. (2000). Challenge to world class manufacturing. International Journal of Quality \& Reliability Management, 17(2), 132-143. http://dx.doi.org/10.1108/02656710010304546

Zairi, M., \& Thiagarajan, T. (1997). A review of total quality management in practice: understanding the fundamentals through examples of best practice applications - Part III. The TQM Magazine, 9(6), 270-286. http://dx.doi.org/10.1108/09544789710181899

\section{Copyrights}

Copyright for this article is retained by the author(s), with first publication rights granted to the journal.

This is an open-access article distributed under the terms and conditions of the Creative Commons Attribution license (http://creativecommons.org/licenses/by/3.0/). 